\title{
Penerapan Metode Waterfall Dalam Aplikasi Penyewaan Lapangan Futsal Akasia Berbasis Web
}

\author{
Puji Astuti ${ }^{1}$, Nia Nuraeni ${ }^{2}$ \\ 1STMIK Nusa Mandiri / Program Studi Teknik Informatika \\ e-mail: puji.pat@nusamandiri.ac.id \\ 2STMIK Nusa Mandiri / Program Studi Teknik Informatika \\ e-mail: nia.nne@nusamandiri.ac.id
}

\begin{abstract}
Futsal adalah salah satu olahraga yang digandrungi kaum remaja. Permainan yang mudah dan simpel membuat olahraga yang satu ini naik daun. Pangsa pasar dalam permintaan lapangan futsal sering sekali terjadi antrean bahkan sampai full setiap harinya, sehingga dibutuhkan aplikasi untuk melihat jadwal yang kosong. Dilingkungan Akasia terdapat lapangan futsal yang dimana selalu ramai. Sistem yang masih manual membuat user merasa kesulitan untuk melakukan reservasi lapangan futsal. Dengan dibuatnya aplikasi penyewaan lapangan futsal akasia ini dapat membantu user dalam melihat adakah lapangan yang kosong saat ingin bermain. Tak perlu jauh-jauh datang ke lokasi untuk menanyakan perihal jadwal kosong pada saat itu, lebih efisien dan efektik dalam proses penyewaan lapangan futsal akasia. Aplikasi ini juga membantu admin dalam pembuatan laporan keuangan.
\end{abstract}

Kata Kunci: aplikasi penyewaan, website, metode waterfall.

\begin{abstract}
Futsal is a sport that is loved by teenagers. An easy and simple game to make this one rising sport. Market share in the futsal field demand often occurs even in full queues every day, so we need an application to see an empty schedule. Acacia environment there is a futsal field which is always crowded. The system is still manual makes users find it difficult to make futsal field reservations. By making this acacia futsal field rental application, it can help the user in seeing if there is an empty field when they want to play. No need to come all the way to the location to ask about the empty schedule at the time, more efficient and effective in the process of leasing the acacia futsal field. This application also helps the admin in making financial statements.
\end{abstract}

Keywords: rental application, website, waterfall method

\section{Pendahuluan}

Penyewaan lapangan futsal adalah sebuah usaha penyewaan yang menyediakan pelayanan jasa penyewaan lapangan futsal.(Rahma, 2015).

Sistem pemesanan lapangan futsal yang sekarang dirasakan kurang efektif karena dapat menghabiskan banyak waktu dalam melakukan pencarian dan pemesanan lapangan futsal.(Ratnasari, Hadi, \& Budiarto, 2018). Dalam jasa penyewaan futsal ini faktor pelayanan mempengaruhi kelancaran operasional dalam informasinya. (Maimunah;
Kesehatan merupakan hal yang penting dalam hidup, bagaimana seseorang dalam menjaga tubuhnya agar tetap sehat dan bugar. Futsal adalah olahraga yang selalu dipilih karena permainannya yang sederhana. Peminat dari futsal biasanya digandrungi dari kaum remaja. Dari kalangan pekerja, mahasiswa bahkan sampai anak-anak menggemari olahraga futsal ini. Olahraga futsal ini bukan hanya digandrungi oleh kaum lelaki ataupun anakanak, bahkan kaum wanita juga menyukai olahraga ini. Selain menjadi tren dan mode olahraga dimasa teknologi seperti ini. 


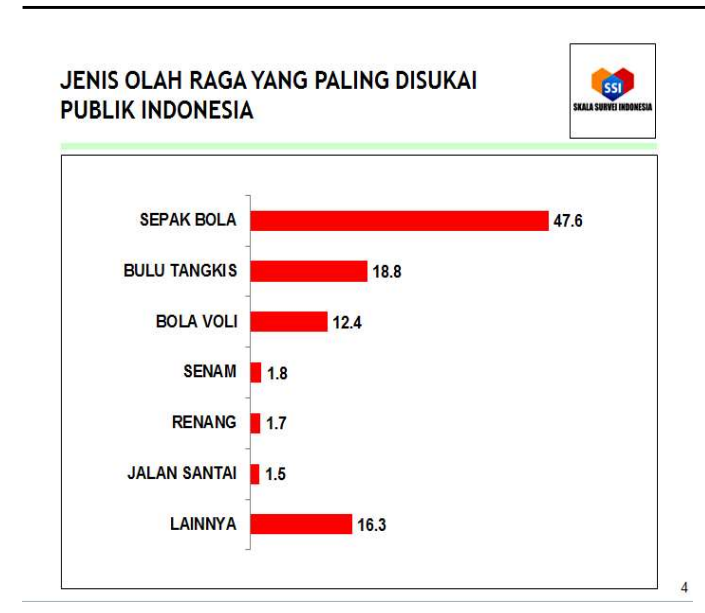

Gambar 1.1 Grafik Survey Olahraga Indonesia

Sumber : (www.skalasurveiindonesia.com)

Banyaknya peminat dalam berolahraga futsal menjadikan tempat penyewaan lapangan futsal sangat ramai, bahkan ketika saat ingin bermain dan memesan dengan datang langsung, terjadi antrean dalam penyewaan lapangan futsal. Proses manual yang terjadi membutuhkan banyak waktu.

Dengan adanya website penyewaan lapangan futsal menjadikan penyewa dengan mudah melihat jadwal yang kosong dan dapat memesan lapangan tersebut susai dengan jadwal yang didapat, lebih efisiensi waktu dan tenaga.

\section{a. Program}

Program yaitu sekumpulan instruksiinstruksi yang diperintahkan kepada komputer untuk melaksanakan atau menampilkan tugas atau pekerjaan. (Janti, 2017).

Program juga diibaratkan sebagai kata, kalimat, sebuah ekpresi dari suatu pernyataan yang dirangkai menjadi satu kesatuan sebuah prosedur yang berupa urutan langkah-langkah untuk menyelesaikan suatu masalah yang di implementasikan dengan menggunakan bahasa pemrograman, dan dapat di terima dan dimengerti oleh komputer.

\section{b. Website}

Web dapat diartikan sebagai kumpulah dari halaman-halaman yang menampilkan informasi data teks, gambar, animasi, suara, audio, video atau gabungan dari semuanya baik yang bersifat statis maupun dinamis yang membentuk suatu rangkaian bagunan yang saling terkait dimana masingmasing dapat dihubungkan dengan

\author{
jaringan halaman.(Maimunah; \\ Hariyansyah; Jihadi, 2017)
}

\section{Metode Penelitian}

a. Teknik Pengumpulan Data

1. Observasi

Metode observasi ini dilakukan dengan melakukan pengematan langsung ke lapangan futsal akasia

2. Studi Pustaka

Metode studi pustaka yang dilakukan dengan mengumpulan bahan dari buku literature, jurnal, internet dalam menunjang penulisan dalam masalah yang ada saat ini.

\section{b. Metode Pengembangan Perangkat Lunak}

Model waterfall sering juga disebut model sekuensi linear atau alur hidup klasik. Pengembangan sistem dikerjakan secara terurut mulai dari analisis, desain, pengkodena, pengujian dan tahap pendukung. (Sukamto \& Shalahudin, 2013). Gambar 1.2 Metode Waterfall

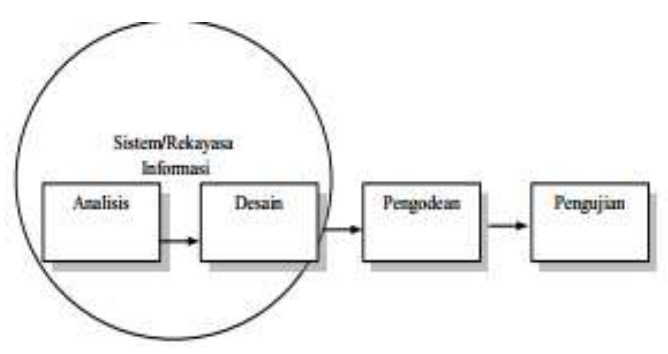

Sumber : (Sukamto \& Shalahudin, 2013)

1. Analisis

Dalam tahap ini penulis mulai menganalisa apa saja kebutuhan dari system maupun kebutuhan dari user.

2. Desain

Merupakan tahapan lanjut dari tahap analisis dimana dalam tahap ini disajikan desain-desain dari aplikasi pembuatan program website penyewaan lapangan futsal.

3. Pengkodean

Menerapkan desain database serta desain antar muka kedalam Bahasa pemrograman, dengan menggunakan software PHP dan Xampp dalam pembuatan website.

4. Pengujian 
Tahap akhir dalam metode waterfall dimana dalam tahap pengujian ini digunakan teknik pengujian blackbox testing.

5. Pendukung

Tahap pendukung atau pemeliharaan dapat mengulangi proses pembangunan mulai dari analisis spesifikasi untuk perubahan perangkat lunak yang sudah ada, tapi tidak untuk membuat perangkat lunak baru. Tahap ini bisa dikatakan final dalam pembuatan suatu aplikasi atau sistem. Setelah melakukan analisis, desain maka sistem ini akan digunakan oleh pengguna. Kemudian aplikasi yang telah dibuat harus dilakukan pemeliharaan.

\section{Hasil dan Pembahasan}

\subsection{Prosedur sistem yang diusulkan}

Prosedur sistem yang penulis usulkan sebagai berikut:

a. Pengolahan Data User

Pengolahan data user dilakukan oleh seorang user yang dibantu oleh seorang administrator. Sebelum melakukan reservasi lapangan futsal akasia, maka user harus mendaftarkan nama anggota grupnya terlebih dahulu, untuk memudahkan dalam proses reservasi.

b. Pengolahan Reservasi Lapangan Futsal Akasia.

Nama grup yang sudah terdaftar melakukan reservasi lapangan futsal akasia yang jadwalnya masih kosong, dan melihat lapangan futsal akasia yang mana yang masih bisa untuk di booking. Setelah melihat gambar dari detailnya maka user bisa reservasi lapangan futsal tersebut.

c. Pengolahan Pembayaran

Setelah melakukan reservasi, user melakukan pembayaran secara full terhadap lapangan futsal akasia yang telah di reservasi.

\subsection{Desain Sistem}

a. ERD (Entity Relationship Diagram) Menurut (Simarmata, 2010) ERD adalah alat pemodelan data utama dan akan membantu mengorganisasi data dalam suatu proyek kedalam entitas-entitas dan menentukan hubungan antar entitas

\section{Gambar 1.2 Diagram ERD Penyewaan Lapangan Futsal Akasia}

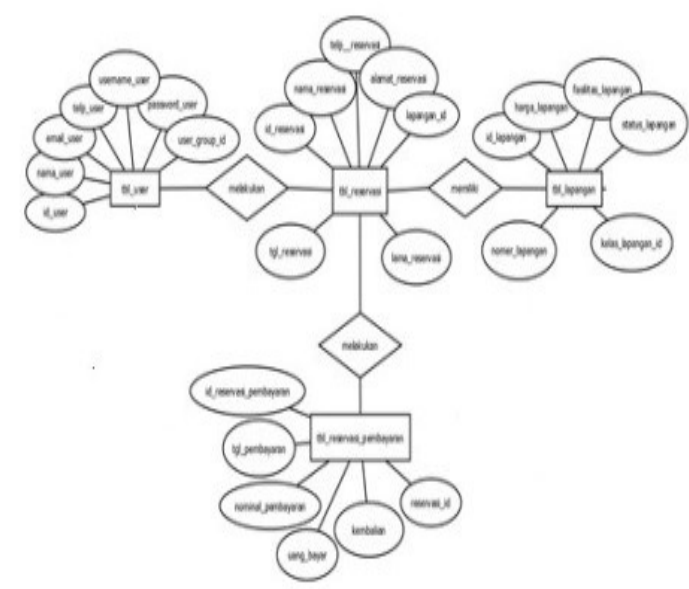

Sumber: Penelitian 2019

\section{b. LRS (Logical Record Structured)}

LRS adalah representasi dari struktur record -record pada tabel-tabel yang terbentuk dari hasil relasi antara himpunan entitas. Menentukan kardinalitas, jumlah tabel, dan Foreign Key (FK). (Simarmata, 2010)

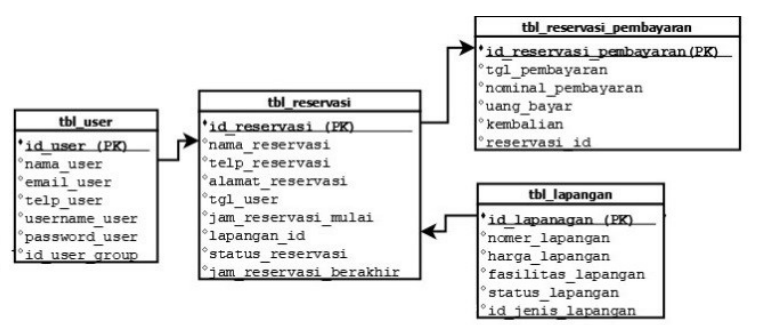

\section{Gambar 1.3 Struktur LRS Penyewaan Lapangan Futsal Akasia}

Sumber: Penelitian 2019

\section{c. UML (Unified Model Language)}

Unified Model Language merupakan sebuah bahasa pemodelan untuk membangun dan merancang seluruh yang ada pada sistem. Tujuan dari model ini untuk menggambarkan bagian yang termasuk dalam lingkup sistem antara hubungan dengan sistem serta subsistem. Use case dapat diartikan sebagai diagram yang dapat mempresentasikan hal yang dapat dilakukan oleh aktor dalam menyelesaikan sebuah proses 
pekerjaan. (Pt \& Rent, 2018)

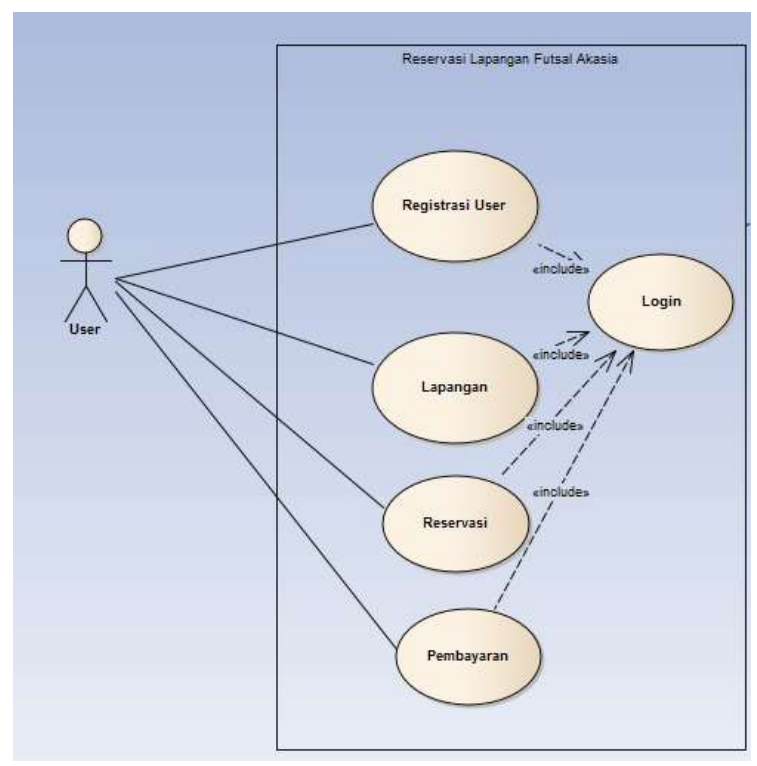

Gambar 1.4 Use Case Reservasi Lapangan Futsal Akasia

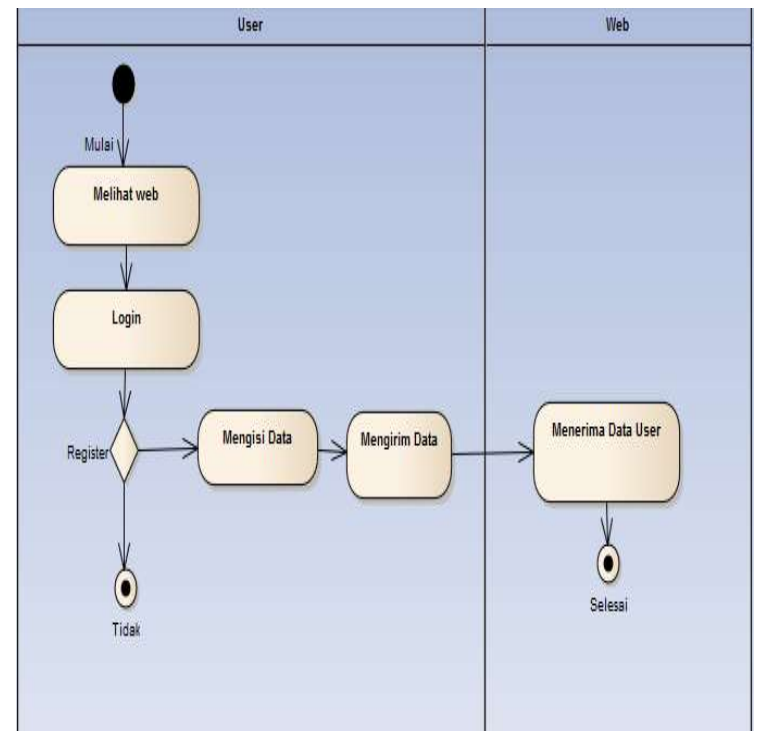

Gambar 1.5 Activity Diagram Login User

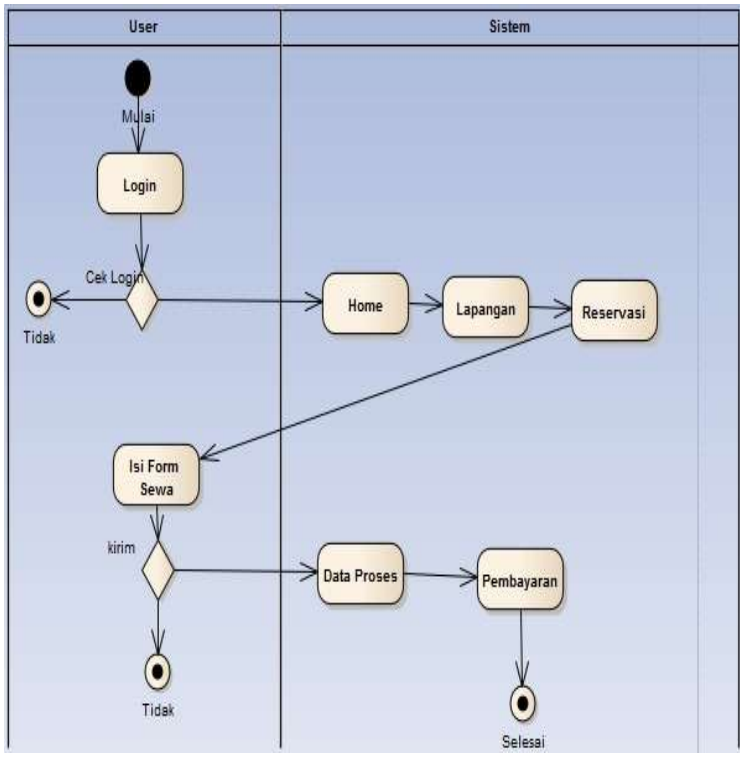

Gambar 1.6 Activity Diagram Reservasi Lapangan Futsal Akasia

\section{d. Tampilan Web}

1. Login User

Login user digunakan bagi user yang ingin melakukan pemesanan lapangan futsal akasia

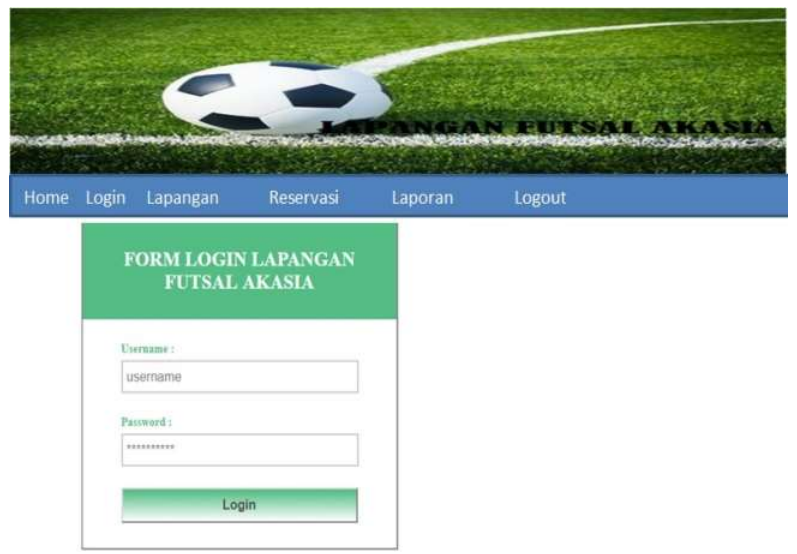

\section{Gambar 1.7 Login User}

2. Tampilan Lapangan

Tampilan lapangan dibuat untuk mengetahui bentuk dan detail dari lapangan tersebut. Di Lapangan Futsal Akasia terdapat dua lapangan. 


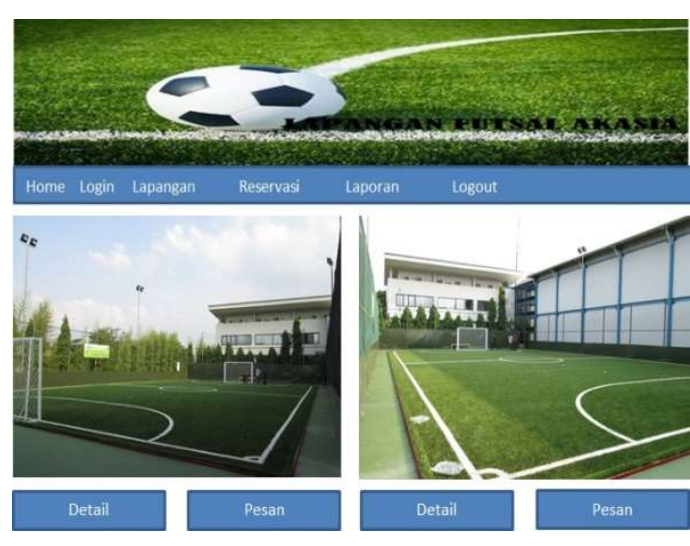

Gambar 1.8 Lapangan Futsal Akasia

3. Tampilan Form Sewa

Ketika user sudah mendaftar dan login, kemudian melihat detail lapangan maka, user masuk ke dalam menu Reservasi. Dan mengisi form serta langsung melakukan pembayaran secara full.
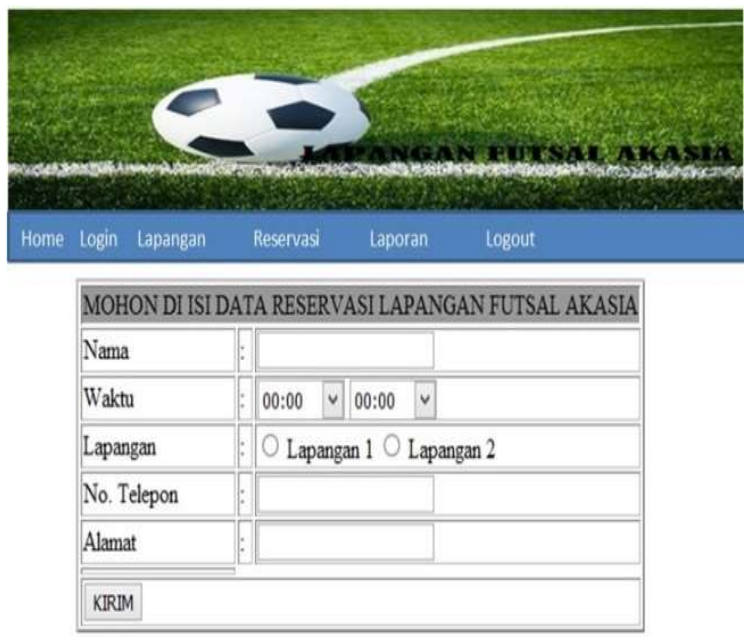

\section{Gambar 1.9 Form Sewa Lapangan Futsal Akasia}

\section{e. Black Box Testing}

Black Box Testing adalah sebuah perangkat lunak yang tidak diketahui kinerja yang ada didalamnya atau internal. (Janti, 2017)
Tabel 1.1 Pengujian Login User

\begin{tabular}{|c|c|c|c|}
\hline Input & Proses & Output & $\begin{array}{l}\text { Hasil } \\
\text { penguj } \\
\text { ian }\end{array}$ \\
\hline $\begin{array}{l}\text { Input } \\
\text { userna } \\
\text { m : } \\
\text { koson } \\
\text { g } \\
\text { passw } \\
\text { ord: } \\
\text { benar }\end{array}$ & $\begin{array}{l}\text { Sistem } \\
\text { akan } \\
\text { mempro } \\
\text { ses } \\
\text { userna } \\
\text { me dan } \\
\text { passwor } \\
\text { d yang } \\
\text { sudah } \\
\text { diinputk } \\
\text { an }\end{array}$ & $\begin{array}{l}\text { Menampi } \\
\text { Ikan hasil } \\
\text { "Passwor } \\
\text { d salah, } \\
\text { mohon isi } \\
\text { ulang" }\end{array}$ & $\begin{array}{l}\text { Tidak } \\
\text { sesuai }\end{array}$ \\
\hline $\begin{array}{l}\text { input } \\
\text { userna } \\
\text { me : } \\
\text { benar } \\
\text { passw } \\
\text { ord : } \\
\text { salah }\end{array}$ & $\begin{array}{l}\text { Sistem } \\
\text { akan } \\
\text { mempro } \\
\text { ses } \\
\text { userna } \\
\text { m dan } \\
\text { passwor } \\
\text { d yang } \\
\text { sudah } \\
\text { diinputk } \\
\text { an }\end{array}$ & $\begin{array}{l}\text { Menampi } \\
\text { lkan hasil } \\
\text { "usernam } \\
\text { e salah, } \\
\text { mohon isi } \\
\text { ulang" }\end{array}$ & $\begin{array}{l}\text { Tidak } \\
\text { sesuai }\end{array}$ \\
\hline $\begin{array}{l}\text { Input } \\
\text { userna } \\
\text { me: } \\
\text { benar } \\
\text { passw } \\
\text { ord: } \\
\text { benar }\end{array}$ & $\begin{array}{l}\text { Sistem } \\
\text { akan } \\
\text { mempro } \\
\text { ses } \\
\text { userna } \\
\text { m dan } \\
\text { passwor } \\
\text { d yang } \\
\text { sudah } \\
\text { diinputk } \\
\text { an }\end{array}$ & $\begin{array}{l}\text { Menampi } \\
\text { Ikan hasil } \\
\text { tampil } \\
\text { menu } \\
\text { index } \\
\text { atau } \\
\text { home }\end{array}$ & sesuai \\
\hline
\end{tabular}

Sumber: Penelitian 2019 
Tabel 1.2 Pengujian Unit Sewa

\begin{tabular}{|l|l|l|l|}
\hline Input & Proses & Output & $\begin{array}{l}\text { Hasil } \\
\text { Penguj } \\
\text { ian }\end{array}$ \\
\hline $\begin{array}{l}\text { Masuk } \\
\text { an } \\
\text { nama, } \\
\text { waktu, } \\
\text { alamat }\end{array}$ & $\begin{array}{l}\text { Mempro } \\
\text { ses } \\
\text { data } \\
\text { yang } \\
\text { dikirimk } \\
\text { an }\end{array}$ & $\begin{array}{l}\text { Kembali } \\
\text { ke form } \\
\text { isi data } \\
\text { sewa } \\
\text { karna } \\
\text { ada data } \\
\text { yang } \\
\text { masih } \\
\text { kosong } \\
\text { sesuai }\end{array}$ & $\begin{array}{l} \\
\text { yaitu } \\
\text { nomor } \\
\text { telepon }\end{array}$ \\
\hline $\begin{array}{l}\text { Mengin } \\
\text { put } \\
\text { semua } \\
\text { data } \\
\text { yang } \\
\text { ada } \\
\text { didala } \\
\text { m form }\end{array}$ & $\begin{array}{l}\text { Mempro } \\
\text { ses } \\
\text { data } \\
\text { yang } \\
\text { sudah } \\
\text { diinputk } \\
\text { an }\end{array}$ & $\begin{array}{l}\text { Menampi } \\
\text { lkan } \\
\text { pesan } \\
\text { "Data } \\
\text { berhasil } \\
\text { tersimpa } \\
\text { n" }\end{array}$ & Sesuai \\
\hline
\end{tabular}

Sumber: Penelitian 2019

\section{Kesimpulan}

Dengan adanya website penyewaan lapangan futsal akasian ini,dapat membantu masyarakat di pemukiman akasia khususnya kalangan remaja dalam mendapatkan informasi jadwal kosong untuk bermain atau olahraga futsal. Tanpa harus datang langsung ke lokasi, user dapat reservasi jadwal yang kosong untuk melakukan proses penyewaan, kapanpun dan dimanapun user mengakses.

\section{Referensi}

Janti, S. (2017). Animasi Edukasi Interaktif Tes Kemampuan Konsentrasi Dengan Permainan Tebak Warna. Jurnal Teknik Komputer AMIK BSI (JTK), III(1), 106-113. https://doi.org/10.1016/j.cropro.2015.0 5.004

Maimunah; Hariyansyah; Jihadi, G. (2017). Rancang Bangun Sistem Aplikasi Penyewaan Lapangan Futsal Berbasis Web. Seminar Nasional Teknologi Informasi Dan Multimedia 2017 STMIK AMIKOM Yogyakarta, 4 Februari 2017 ISSN 2302-3805, 7-12.

Pt, P., \& Rent, A. P. M. (2018). Jurnal Usecase, 2(2), 64-77.

Rahma, N. A. (2015). Aplikasi Penyewaan Lapangan Futsal Berbasis WEB dan SMS Gateway. E-Proceeding of Applied Science, 1(1), 663.

Ratnasari, D., Hadi, H. F., \& Budiarto, J. (2018). Rancang Bangun Aplikasi Penyewaan Lapangan Futsal Berbasis Android. JUTI: Jurnal IImiah Teknologi Informasi, 16(2), 144. https://doi.org/10.12962/j24068535.v1 6i2.a738

Simarmata, J. (2010). Perancangan Basis Data. Yogyakarta: CV. Andi Offset.

Sukamto, R., \& Shalahudin, M. (2013). No Title. Bandung: Informatika. 